bringing the mistake to the attention of the court. He granted a faculty for the exhumation and reburial of $\mathrm{H}$ in the churchyard with the costs of this process, and the court costs, to be paid by the incumbent. [WA]

doi:10.1017/So956618X10000670

\title{
Re St Dunstan, Cheam
}

Southwark Consistory Court: Petchey Ch, April 2010 Church hall - disused burial ground

In granting a faculty for the erection of a hall as a separate building falling partly within the consecrated churchyard and partly outside, the chancellor considered whether section 2 of the Disused Burial Grounds Act 1884 had the effect of preventing the construction of the hall. The section states 'It shall not be lawful to erect any buildings upon any disused burial ground, except for the purpose of enlarging a church, chapel, meeting house, or other place of worship.' The chancellor found that, whilst the churchyard was no longer used for the interment of bodies, it was still used for the interment of cremated remains and had not been closed by Order in Council. The 1884 Act did not, therefore, apply. [WA]

\section{Re St Michael and All Angels, Sandhurst}

Arches Court of Canterbury: George, Dean, May 2010 Leave to appeal - Human Rights Act - memorials - 'Gypsy way of life'

At a hearing to determine four petitions in relation to the same churchyard, the chancellor had refused a faculty for the erection of a memorial over the grave of the applicants' son and granted one for the reservation of the adjoining gravespaces for the applicants. He stated that the reservation and any future permission for a headstone would be conditional upon no unauthorised items or memorials being placed on the grave or reserved gravespaces. The proposed memorial was outside the diocesan churchyard regulations in a number of respects, including the size, material and shape of the headstone, the inclusion of kerbs and the use of an etched photograph and coloured paint. After the refusal the memorial was unlawfully erected in the churchyard. The chancellor adjourned the hearing of the archdeacon's application for the removal of the memorial to enable the applicants to seek leave to appeal out of time to the Court of Arches and to seek a declaration of incompatibility under the Human Rights Act 1998 in the High Court. Upon the applicants' application to the Court of Arches the Dean approved the chancellor's decision to hear 